Giseli Nogueira Damacena

Célia Landmann Szwarcwald

Paulo Roberto Borges de Souza Júnior

\section{HIV risk practices by female sex workers according to workplace}

\author{
Práticas de risco ao HIV de \\ mulheres profissionais do sexo
}

\begin{abstract}
OBJECTIVE: To investigate differences in HIV infection- related risk practices by Female Sex Workers according to workplace and the effects of homophily on estimating HIV prevalence.

METHODS: Data from 2,523 women, recruited using Respondent-Driven Sampling, were used for the study carried out in 10 Brazilian cities in 2008-2009. The study included female sex workers aged 18 and over. The questionnaire was completed by the subjects and included questions on characteristics of professional activity, sexual practices, use of drugs, HIV testing, and access to health services. HIV quick tests were conducted. The participants were classified in two groups according to place of work: on the street or indoor venues, like nightclubs and saunas. To compare variable distributions by place of work, we used Chi-square homogeneity tests, taking into consideration unequal selection probabilities as well as the structure of dependence between observations. We tested the effect of homophily by workplace on estimated HIV prevalence.
\end{abstract}

RESULTS: The highest HIV risk practices were associated with: working on the streets, lower socioeconomic status, low regular smear test coverage, higher levels of crack use and higher levels of syphilis serological scars as well as higher prevalence of HIV infection. The effect of homophily was higher among sex workers in indoor venues. However, it did not affect the estimated prevalence of HIV, even after using a post-stratification by workplace procedure.

CONCLUSIONS: The findings suggest that strategies should focus on extending access to, and utilization of, health services. Prevention policies should be specifically aimed at street workers. Regarding the application of Respondent-Driven Sampling, the sample should be sufficient to estimate transition probabilities, as the network develops more quickly among sex workers in indoor venues.

DESCRIPTORS: Sex Workers. Dangerous Behavior. HIV Seroprevalence. Risk Factors. Workplace.
Laboratório de Informações em Saúde.
Instituto de Comunicação e Informação

Científica e Tecnológica em Saúde. Fundação

Oswaldo Cruz. Rio de Janeiro, RJ, Brasil

\section{Correspondence:}

Giseli Nogueira Damacena

Laboratório de Informações em Saúde - Icict/

Fiocruz

Av. Brasil, 4365 Sala 225 Pavilhão Haity

Moussatché

21040-900 Rio de Janeiro, RJ, Brasil

E-mail: damacenagn@gmail.com

Received: 6/13/2013

Approved: 10/21/2013 


\section{RESUMO}

OBJETIVO: Investigar diferenças nas práticas de risco à infecção pelo HIV segundo local de trabalho das mulheres profissionais do sexo e efeitos de homofilia na estimação da prevalência do HIV.

MÉTODOS: Foram utilizadas informações de 2.523 mulheres recrutadas por Respondent-Driven Sampling em estudo realizado em 10 cidades brasileiras, 20082009. Foram incluídas profissionais com 18 anos ou mais de idade. O questionário foi autopreenchido e incluiu perguntas sobre características da profissão, práticas sexuais, uso de drogas, testes periódicos de HIV e acesso aos serviços de saúde. Utilizaram-se testes rápidos para detecção de HIV. As participantes foram agregadas em dois grupos por local de trabalho: pontos de rua ou locais fechados, e.g., boates, saunas e termas. Foram utilizados testes Qui-quadrado de homogeneidade, levando-se em consideração as probabilidades desiguais de seleção, bem como a dependência entre as observações. Os efeitos de homofilia por local de trabalho foram pesquisados na estimação da prevalência do HIV.

RESULTADOS: As práticas de maior risco ao HIV associaram-se a: trabalhar em pontos de rua, menor nível socioeconômico, baixa cobertura de exame preventivo de câncer de colo de útero, elevado consumo de crack, maior prevalência de cicatriz sorológica de sífilis e maior prevalência de infecção pelo HIV. O efeito de homofilia foi maior entre as profissionais de locais fechados. Contudo, não afetou a estimativa da prevalência de HIV, mesmo utilizando o procedimento de pós-estratificação por local de trabalho.

CONCLUSÕES: Os resultados indicaram que as estratégias devem ser dirigidas à ampliação do acesso e à utilização dos serviços de saúde. As políticas de prevenção devem priorizar as profissionais de rua. Em relação à aplicação do Respondent-Driven Sampling, a amostra deve ser suficiente para estimação das probabilidades de transição, uma vez que a rede se desenvolve mais rapidamente entre as profissionais de locais fechados.

DESCRITORES: Profissionais do Sexo. Comportamento Perigoso. Soroprevalência de HIV. Fatores de Risco. Local de Trabalho.'

\section{INTRODUCTION}

It is necessary to monitor the practices and attitudes of those most at risk of HIV infection, as specific interventions aimed at these population subgroups can significantly alter the pattern of the spread of HIV and AIDS in the general population. ${ }^{5}$

Research on female sex workers (FSW) confirms the increased risk of HIV infection in this population subgroup. Lack of access to health care services, drug abuse and prior history of sexually transmitted infection have also been shown, and are also factors associated with HIV prevalence. ${ }^{20,23}$ Recent studies emphasize the importance of characterizing FSW practice according to workplace. Practices placing them at risk of HIV infection may vary according to where the FSW meet their clients (indoor venues or on the street). ${ }^{4,7,20,21}$
Until recently, convenience sampling was used in studies of this type, due to the difficulties in using traditional sampling techniques to select individuals in populations with high risk of HIV infection..$^{25}$ These studies were also local, limiting monitoring of national level prevention actions and policies. ${ }^{3}$

The development of probabilistic sampling methods specifically for selecting individuals at greater risk of contracting HIV, such as Respondent-Driven Sampling (RDS), ${ }_{14}^{14}$ gave new opportunities for both international ${ }^{22}$ and national research. ${ }^{17}$

RDS is considered to be a variant of chain sampling. However, it was developed based on assumptions that allow the probability of selection to be calculated. ${ }^{26}$ Recruiting individuals using RDS assumes that 
individuals with a certain characteristic or participating in a certain activity are interlinked through a social network and have connections with others with similar characteristics. The data are collected in successive recruitment circles, known as "waves". ${ }^{14}$ The method sometimes produces the so-called "homophily effect", a result of the tendency of the individual selected for the study to recruit others with similar charateristics. ${ }^{15}$

In 2008 and 2009, a study with FSW was conducted in 10 cities in Brazil, with RDS chosen as the sampling methodology. ${ }^{10,11,28}$ Based on the data from this study, Szwarcwald et $\mathrm{al}^{28}$ proposed a method of analyzing data collected using RDS, taking into consideration unequal probability of selection as well as dependency between observations, given the recruitment pattern as well as intraclass variation in the group of participants recruited by the same person. Moreover, the analysis can be conducted using logistic regression, enabling the model to be extended to a multivariate model. The prevalence of HIV was estimated at $4.8 \%$ (95\% CI $3.4 ; 6.1)$, approximately 15 times greater in this group than in the female Brazilian population. ${ }^{27}$ Multivariate analysis showed that the length of time in prostitution, charging low prices, presence of other sexually transmitted infections and the possibility of being pressured by the client not to use protection were the main predictors of HIV in Brazilian FSW. ${ }^{11}$

This article aimed to investigate differences in HIV infection-related practices in female sex workers according to the workplace, and the effects of homophily in estimating HIV prevalence.

\section{METHODS}

Data were taken from the study on sexually transmitted infections in sex workers, which took place between August 2008 and July 2009 in 10 Brazilian cities (Manaus, Recife, Salvador, Campo Grande, Brasília, Belo Horizonte, Santos, Rio de Janeiro, Curitiba and Itajaí).

The cities were chosen by the Brazilian Ministry of Health Department of Sexually Transmitted Diseases, AIDS and Viral Hepatitis due to their location and the scale of the HIV/AIDS epidemic.

In total, 2,523 FSW aged 18 and over, who had had sex in exchange for money on at least one occasion in the four months preceding the study, were included. The sample was proportional to the population of each city, although with a minimum of $100 \mathrm{FSW}^{10}$

In each city, 10 initial participants, so-called "seeds", were chosen. The choice of seeds was not random, as it was to include FSW of different ages groups, skin color/race, economic class, level of schooling and from different workplaces, e.g., on the street, in nightclubs, saunas, and hotels, among others. Each seed received three coupons to pass on to acquaintances who were also sex workers. Those seeds invited to participate in the research formed the first "wave" of the study. After participating in an interview they in turn received three more coupons to invite their acquaintances. This process was repeated until the required sample for each city was reached.

The data were collected using a questionnaire in an Audio Computer-Assisted Self-Interview. The FSW were provided with laptop computers and headphones with which to read and listen to all of the questions and response options in private. Studies conducted in the USA indicate that interview methods that increase privacy in the context of the interview dramatically increase reports regarding sensitive and/or illegal behavior. ${ }^{1,18}$ They also indicated that the participants had no difficulty in using the equipment. ${ }^{24,25, a}$

HIV diagnosis was obtained using the rapid test, following the protocols of the Department of Sexually Transmitted Diseases, AIDS and Viral Hepatitis. To verify any association with the prevalence of syphilis with that of HIV, the disease was tested for using the Bio-Line rapid treponemal test for syphilis which gave a diagnosis of active syphilis. Negative or positive VDRL tests below 1:8 were considered to be a syphilis serologic scar. All participants received preand post-test counselling. Women with positive results received additional post-test counselling, both in order to deal with the psychological impact and to encourage partners to be tested if necessary, and were referred to public health care services for follow up.

The assumptions of the RDS method and the experience of establishing this sampling process in sex workers in Brazil are described in a previous publication. ${ }^{10}$

The size of the FSW network of acquaintances was estimated using the question: "How many sex workers working here in the city do you know personally?", and sampling weights proportional to the inverse of the size of the participants' network were used. ${ }^{26}$ The total sample was calibrated using post-stratification procedures, considering the relative size of the group of 18 to 59-year-old women in each city and assuming the same proportion of FSW in all cities. ${ }^{28}$

The FSW were separated into two groups according to their workplace: the "on the street" group composed of those who worked on the street and in brothels; and the "indoor venues" group, made up of women who worked in nightclubs, bars, hotels, motels, saunas and massage parlors.

${ }^{a}$ Rogers SM, Miller HG, Forsyth BH, Smith TK, Turner CF. Audio-CASI: the impact of operational characteristics on data quality. Joint Proceedings of the American Association for Public Opinion Research. 1996; Alexandria; US. Alexandria: American Statistical Association, Survey Methods Research Section; 1996. 
The following aspects were used to investigate differences according to workplace: sociodemographic variables, characteristics of the FSW work, frequency of alcohol and illegal drug use, health service access indicators and the results of the HIV and syphilis tests. Indicators of condom use were not used as they show no significant association with HIV infection. ${ }^{11}$

The comparative analysis used the Chi-square tests for homogeneity between distributions, taking into consideration unequal probabilities of selection as well as dependence between observations given the intra-class variation between participants recruited by the same individual. The "Complex Sample" appendix from the Statistical Package for the Social Sciences 17.0 was used, considering the group of women invited by the same FSW as a cluster.

To verify homophily according to workplace, the recruitment network was analyzed identifying the workplace of the recruiter and the recruitee, using the NetDraw program. ${ }^{6}$ Estimates of the proportion of FSW in each stratum and the homophily test were conducted using estimates of the probability of transition from one state (the street) to the other (indoor venue), using the method proposed by Szwarcwald et al. ${ }^{28}$

Additionally, the possible effects of homophily according to workplace in estimating HIV prevalence were also investigated. Considering stratification according to workplace, the estimate of HIV prevalence is found by:

$$
\mathrm{P}(\mathrm{HIV})=\mathrm{p} 1 * \mathrm{P}(\mathrm{HIV} \mid 1)+\mathrm{p} 2 * \mathrm{P}(\mathrm{HIV} \mid 2),
$$

In which $\mathrm{i}=1$ and 2 represent strata and $\mathrm{P}(\mathrm{HIV} \mid \mathrm{i})$, the prevalence of HIV in stratum i.

The research was approved by the Research Ethics Committee of the Fundação Oswaldo Cruz (Protocol 395/07)

\section{RESULTS}

There were 2,523 interviews, excluding those of the seeds, distributed among the 10 cities: Manaus (199), Recife (237), Salvador (260), Campo Grande (147), Brasília (308), Belo Horizonte (289), Santos (191), Rio de Janeiro (601), Curitiba (201) and Itajaí (90).

When comparing the sociodemographic characteristics of the FSW according to workplace, with the exception of race, all the variables studied showed statistically significant differences at the $5 \%$ level. Comparing distributions according to age, the majority of young women (18 to 24 years old) were found in the "indoor venue" group, whereas the majority of FSW aged 40 and over were in the "on the street" group. In regard to socioeconomic status, FSW in indoor venues had higher levels of schooling and income above R\$1,200.00 (Table 1).
As for the characteristics of the study, those women who worked in indoor venues had spent a comparatively shorter time in prostitution and performed a higher number of sexual activities per day, as well as charging more (Table 2). As to the frequency of alcohol consumption, the differences between workplaces were statistically significant, at the $5 \%$ level of significance, with higher consumption among those women who worked in indoor venues (Table 2). Use of crack or merla was more frequently observed in women working on the streets. The declared percentage of cocaine used was high in both groups (Table 2). Whether cocaine was snorted or injected did not differ significantly according to workplace.

The results shown in Table 3 show the differences in accessing the health care system. In general, FSW working in indoor locations showed higher percentages of gynecological screening examinations and having been tested for syphilis at least once. However, there were no differences in receiving condoms or frequency of HIV testing.

There were some significant differences in the presence of sexually transmitted diseases (Table 3 ). The percentage of FSW on the streets with a syphilis serologic scar was $24.2 \%$, almost 10 percentage points above those who worked in indoor locations (15.5\%). The prevalence of HIV was also significantly higher among sex workers on the street (7.2\%); twice as high as in the other group (3.6\%).

Homophily was observed in the recruitment pattern according to workplace. The probability of a woman working in an indoor venue being recruited by another from an indoor venue was $65.4 \%$, but the probability of being recruited by a woman working on the streets was only $34.6 \%$, indicating homophily (Table 4 ). On balance, the estimated proportion of FSW from indoor venues is $59.0 \%$ and street workers $41.0 \%$. Considering stratification by workplace, the weighted estimate of the prevalence of HIV was of $5.0 \%$.

The tendency to recruit peers from the same stratum by workplace is illustrated in the Rio de Janeiro network (Figure).

\section{DISCUSSION}

The results show differences in the FSW profiles according to workplace. Women who work on the streets had a higher probability of becoming infected with HIV. Older women with lower levels of schooling and income who work on the streets and who have spent longer in prostitution were associated with higher risk of becoming HIV infected, as has been discussed by other authors. ${ }^{20} \mathrm{~A}$ recent study ${ }^{13}$ showed that FSW aged 50 and over, as well as having been exposed for 
Table 1. Sociodemographic characteristics of sex workers according to workplace. Brazil, 2009. $(\mathrm{N}=2,523)$

\begin{tabular}{|c|c|c|c|c|c|c|c|}
\hline \multirow{3}{*}{ Variable } & \multicolumn{6}{|c|}{ Workplace } & \multirow{3}{*}{$\mathrm{p}$} \\
\hline & \multicolumn{2}{|c|}{ On the street ${ }^{a}$} & \multicolumn{2}{|c|}{ Indoor venues ${ }^{b}$} & \multicolumn{2}{|c|}{ Total } & \\
\hline & $\mathrm{n}$ & $\%$ & $\mathrm{n}$ & $\%$ & $\mathrm{n}$ & $\%$ & \\
\hline Age (years) & & & & & & & $<0.001$ \\
\hline 18 to 24 & 307 & 29.7 & 551 & 37.0 & 858 & 34.0 & \\
\hline 25 to 39 & 457 & 44.3 & 743 & 49.9 & 1,200 & 47.6 & \\
\hline 40 to 59 & 248 & 24.0 & 187 & 12.5 & 435 & 17.2 & \\
\hline 60 and over & 20 & 2.0 & 10 & 0.7 & 30 & 1.2 & \\
\hline Total & 1,032 & 100.0 & 1,491 & 100.0 & 2,523 & 100.0 & \\
\hline Schooling & & & & & & & $<0.001$ \\
\hline Elementary school unfinished & 704 & 68.2 & 790 & 53.0 & 1,494 & 59.2 & \\
\hline High school unfinished & 211 & 20.5 & 387 & 26.0 & 598 & 23.7 & \\
\hline High school or above & 117 & 11.4 & 314 & 21.0 & 431 & 17.1 & \\
\hline Total & 1,032 & 100.0 & 1,491 & 100.0 & 2,523 & 100.0 & \\
\hline Skin color & & & & & & & 0.315 \\
\hline White & 232 & 22.5 & 372 & 24.9 & 604 & 23.9 & \\
\hline Black & 286 & 27.7 & 431 & 28.9 & 717 & 28.4 & \\
\hline Mixed race & 425 & 41.2 & 537 & 36.0 & 962 & 38.1 & \\
\hline Other & 89 & 8.6 & 151 & 10.1 & 240 & 9.5 & \\
\hline Total & 1,032 & 100.0 & 1,491 & 100.0 & 2,523 & 100.0 & \\
\hline Marital status & & & & & & & 0.002 \\
\hline Never married & 512 & 49.6 & 820 & 55.0 & 1,332 & 52.8 & \\
\hline Married or cohabiting & 191 & 18.5 & 323 & 21.6 & 514 & 20.3 & \\
\hline Separated or divorced & 249 & 24.1 & 296 & 19.9 & 545 & 21.6 & \\
\hline Widowed & 80 & 7.8 & 52 & 3.5 & 132 & 5.2 & \\
\hline Total & 1,032 & 100.0 & 1,491 & 100.0 & 2,523 & 100.0 & \\
\hline Monthly income (reais) & & & & & & & $<0.001$ \\
\hline 1.00 to 299.00 & 280 & 32.0 & 191 & 14.6 & 471 & 21.6 & \\
\hline 300.00 to 599.00 & 290 & 33.1 & 375 & 28.8 & 665 & 30.5 & \\
\hline 600.00 to $1,199.00$ & 205 & 23.4 & 395 & 30.2 & 600 & 27.5 & \\
\hline $1,200.00$ to $2,999.00$ & 83 & 9.5 & 290 & 22.2 & 373 & 17.1 & \\
\hline $3,000.00$ and over & 18 & 2.0 & 55 & 4.2 & 73 & 3.3 & \\
\hline Total & 876 & 100.0 & 1,306 & 100.0 & 2,182 & 100.0 & \\
\hline
\end{tabular}

${ }^{a}$ On the street and in brothels, predominantly.

${ }^{\mathrm{b}}$ Clubs, bars, hotels, motels, saunas and massage parlors.

a longer time, having spent more years in the profession, are also more likely to have experienced unsafe sexual practices. The findings of this study show that FSW working on the streets had less access to the health care system. The coverage of cervical cancer screening among FSW in indoor venues in the three years preceding the research was $61.8 \%$, lower than that of the 18 to 69 -year old Brazilian female population
(77.3\%), (estimated using data from the 2008 PNAD National Household Survey Health Care Supplement $\left.{ }^{b}\right)$. In FSW who worked on the streets, coverage was lower still; only $53.0 \%$.

The amount the women charged was shown to be a relevant factor, being significantly lower among those who worked on the street. According to the amount charged,

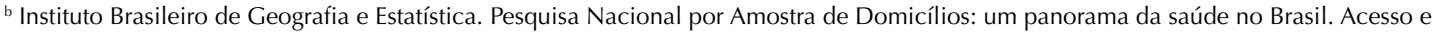
utilização dos serviços, condições de saúde e fatores de risco e proteção à saúde 2008. Rio de Janeiro; 2010 [cited 2012 Dec 5]. Available from: http://www.ibge.gov.br/home/estatistica/populacao/panorama_saude_brasil_2003_2008/PNAD_2008_saude.pdf 
Table 2. Characteristics of work, alcohol and drug consumption in sex workers according to workplace. Brazil, 2009. ( N =2,523)

\begin{tabular}{|c|c|c|c|c|c|c|c|}
\hline \multirow{3}{*}{ Variable } & \multicolumn{7}{|c|}{ Workplace } \\
\hline & \multicolumn{2}{|c|}{ On the street ${ }^{\mathrm{a}}$} & \multicolumn{2}{|c|}{ Indoor venues ${ }^{b}$} & \multicolumn{2}{|c|}{ Total } & \multirow{2}{*}{$\mathrm{p}$} \\
\hline & $\mathrm{n}$ & $\%$ & $\mathrm{n}$ & $\%$ & $\mathrm{n}$ & $\%$ & \\
\hline Length of time working as a sex worker (years) & & & & & & & $<0.001$ \\
\hline Less than 1 & 55 & 5.4 & 130 & 8.8 & 185 & 7.4 & \\
\hline 1 to 3 & 229 & 22.3 & 526 & 35.4 & 755 & 30.1 & \\
\hline 4 to 9 & 296 & 28.9 & 466 & 31.4 & 763 & 30.4 & \\
\hline 10 to 19 & 258 & 25.0 & 236 & 16.0 & 493 & 19.6 & \\
\hline 20 or more & 189 & 18.4 & 125 & 8.4 & 314 & 12.5 & \\
\hline Total & 1,027 & 100.0 & 1,483 & 100.0 & 2,510 & 100.0 & \\
\hline Number of 'tricks' per day & & & & & & & 0.024 \\
\hline 1 to 5 & 836 & 81.0 & 1,112 & 74.6 & 1,948 & 77.2 & \\
\hline 6 to 10 & 144 & 13.9 & 262 & 17.6 & 406 & 16.1 & \\
\hline 11 or more & 52 & 5.0 & 117 & 7.8 & 169 & 6.7 & \\
\hline Total & 1,032 & 100.0 & 1,491 & 100.0 & 2,523 & 100.0 & \\
\hline Charge (reais) & & & & & & & $<0.001$ \\
\hline 1.00 to 29.00 & 448 & 43.4 & 393 & 26.3 & 841 & 33.3 & \\
\hline 30.00 to 49.00 & 304 & 29.4 & 322 & 21.6 & 626 & 24.8 & \\
\hline 50.00 to 99.00 & 184 & 17.8 & 408 & 27.4 & 592 & 23.5 & \\
\hline 100.00 and over & 96 & 9.3 & 368 & 24.7 & 464 & 18.4 & \\
\hline Total & 1,032 & 100.0 & 1,491 & 100.0 & 2,523 & 100.0 & \\
\hline Frequency of alcohol consumption & & & & & & & $<0.001$ \\
\hline Never & 321 & 31.1 & 342 & 22.9 & 663 & 26.3 & \\
\hline Moderate (around once a week or less) & 469 & 45.4 & 691 & 46.4 & 1,160 & 46.0 & \\
\hline Elevated (several times a week or every day) & 242 & 23.4 & 458 & 30.7 & 700 & 27.7 & \\
\hline Total & 1,032 & 100.0 & 1,491 & 100.0 & 2,523 & 100.0 & \\
\hline Frequency crack or merla use & & & & & & & $<0.001$ \\
\hline Never & 900 & 87.2 & 1,412 & 94.7 & 2,312 & 91.6 & \\
\hline Once a month or more & 132 & 12.8 & 79 & 5.3 & 211 & 8.4 & \\
\hline Total & 1,032 & 100.0 & 1,491 & 100.0 & 2,523 & 100.0 & \\
\hline Frequency of snorting or injecting cocaine & & & & & & & 0.455 \\
\hline Never & 841 & 81.5 & 1,188 & 79.7 & 2,029 & 80.4 & \\
\hline Once a month or more & 191 & 18.5 & 303 & 20.3 & 494 & 19.6 & \\
\hline Total & 1,032 & 100.0 & 1,491 & 100.0 & 2,523 & 10.0 & \\
\hline
\end{tabular}

a On the street and in brothels, predominantly.

${ }^{\mathrm{b}}$ Clubs, bars, hotels, motels, saunas and massage parlors.

the clients differed regarding level of schooling and knowledge of HIV transmission, ${ }^{10,29}$ frequently demanding unprotected sex, offering more money for this. ${ }^{16}$ The FSW, in turn, are not able to negotiate safe sex as they need the money. ${ }^{19}$

Charging low prices and the possibility of unprotected sex due to clients' demands are among the main variables associated with HIV prevalence. ${ }^{11}$ Empowering women to negotiate safe sex with partners is considered to be one of the most relevant interventions in reducing HIV transmission in FSW. ${ }^{9}$
Using crack was another factor which proved to be more relevant in street FSW. Studies have shown that drug abuse is associated with a significantly higher risk of becoming infected with HIV, as it can influence unsafe sexual practices. ${ }^{23}$ The need for money to buy drugs is another factor which affects negotiations for safe sex. ${ }^{8,24}$ A study reviewing articles on FSW in Central Asia concluded that the HIV transmission risk factor was the use of illicit drugs, both injectable and non-injectable. ${ }^{2}$

The results of this study also show that women who meet their clients on the street are more subject to sexually transmitted infections and have a higher prevalence 


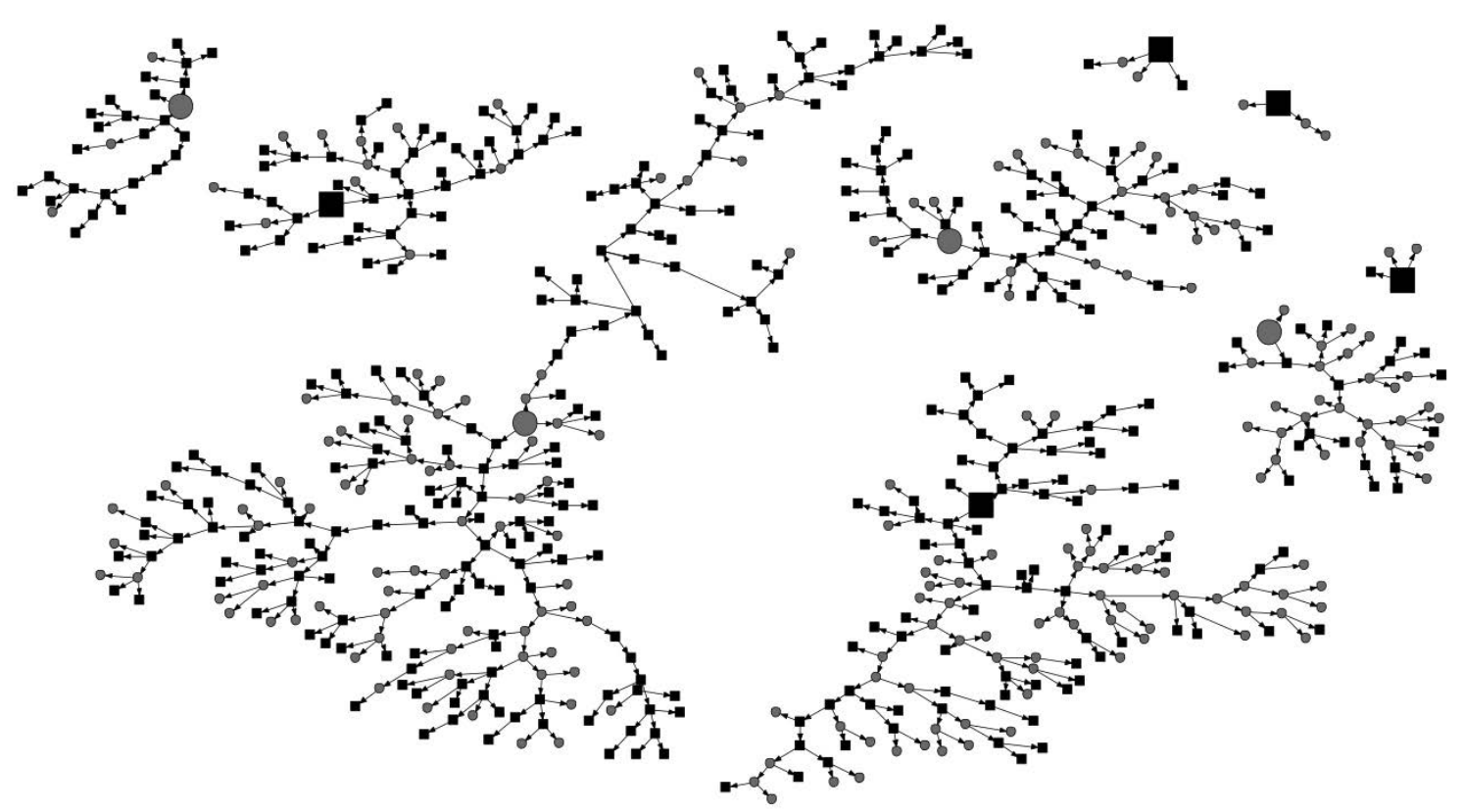

Key: Larger items represent the seeds in the study. The circles represent female sex workers working on the street and the squares those in indoor venues.

Figure. Network of female sex workers who participated in the study according to workplace. Rio de Janeiro, RJ, 2009. (N=601)

of syphilis and HIV. The difference in syphilis serologic scars was almost 10 percentage points higher among those who worked on the streets, corroborating the findings of other studies..$^{20,30}$

Findings in the international literature corroborate the results depicted here, indicating that FSW on the streets are those most at risk of becoming infected with HIV. ${ }^{21}$ Moreover, differing attitudes and practices emphasize the need for studies which take into account separation according to workplace, to properly guide prevention and care actions for FSW. 4,7,20,21

As it uses peer recruitment techniques, in which the participant invites others with similar characteristics, the RDS method is recognized as probabilistic sampling which enables recruitment of individuals in populations to which it is difficult to gain access. ${ }^{22}$ In Brazil, as well as enabling gaps in information concerning the FSW population to be filled, using RDS enables estimates of parameters to be calculated in order to monitor the HIV epidemic in this population subgroup..$^{10,11,28}$

As to the use of the RDS methodology, the findings indicate that FSW on the street recruit FSW who work in indoor venues, and vice-versa, with the networks not being independent. However, attention should be paid to the existence of homophily, especially concerning the tendency of participants from indoor venues to recruit peers from the same group. Firstly, it indicates the need to choose seeds diversified by type of workplace. Secondly, it emphasizes the need to incorporate the dependency of observations produced by the recruiting pattern in the statistical analysis. Lastly, and perhaps most importantly, the sample size should be sufficiently large to estimate the probabilities of transition from one state to another. As the homophily effect did not occur in FSW working on the street, but only in those working in indoor venues, the network developed more quickly among FSW in indoor venues.

Considering the transference process of sampling methods in populations to which it is difficult to gain access, conducted by the Global AIDS Program, Centers of Disease Control, a pilot study in Brazil, conducted in the city of Santos, SP, Southeastern Brazil, used the RDS method to select 173 FSW. Of these, 121 (70.0\%) worked in nightclubs, of which $116(96.0 \%)$ were concentrated in just two clubs. ${ }^{3}$ As the network developed more quickly among FSW in indoor venues, the sample size needed to estimate the probability of transition and the proportions of FSW according to workplace was not reached, probably resulting in underestimation of HIV prevalence.

This limitation does not apply to this study, as the sample was sufficient to achieve Markov equilibrium and the homophily effect did not affect the estimated HIV prevalence. The estimate was very close to what had been found previously, ${ }^{28}$ even using the procedure of post-stratification according to workplace.

To conclude, the results suggest that strategies in the health care sector should increase access to and use of health care services, reducing inequality in coverage 
Table 3. Access to health care and results of HIV and syphilis tests in sex workers according to workplace. Brazil, 2009. ( N =2,523)

\begin{tabular}{|c|c|c|c|c|c|c|c|}
\hline \multirow{3}{*}{ Variable } & \multicolumn{6}{|c|}{ Workplace } & \multirow{3}{*}{$\mathrm{p}$} \\
\hline & \multicolumn{2}{|c|}{ On the street ${ }^{a}$} & \multicolumn{2}{|c|}{ Indoor venues ${ }^{b}$} & \multicolumn{2}{|c|}{ Total } & \\
\hline & $\mathrm{n}$ & $\%$ & $\mathrm{n}$ & $\%$ & $\mathrm{n}$ & $\%$ & \\
\hline $\begin{array}{l}\text { Gynecological consultation with Pap smear in } \\
\text { last three years }\end{array}$ & & & & & & & 0.002 \\
\hline Yes & 547 & 53.0 & 922 & 61.8 & 1,469 & 58.2 & \\
\hline No & 485 & 47.0 & 569 & 38.2 & 1,054 & 41.8 & \\
\hline Total & 1,032 & 100.0 & 1,491 & 100.0 & 2,523 & 100.0 & \\
\hline Bought condoms & & & & & & & $<0.001$ \\
\hline Yes & 608 & 58.9 & 1,077 & 72.2 & 1,685 & 66.8 & \\
\hline No & 424 & 41.1 & 414 & 27.8 & 838 & 33.2 & \\
\hline Total & 1,032 & 100.0 & 1,491 & 100.0 & 2,523 & 100.0 & \\
\hline Received condoms & & & & & & & 0.486 \\
\hline Yes & 808 & 78.3 & 1,139 & 76.4 & 1,947 & 77.2 & \\
\hline No & 224 & 21.7 & 352 & 23.6 & 576 & 22.8 & \\
\hline Total & 1,032 & 100.0 & 1,491 & 100.0 & 2,523 & 100.0 & \\
\hline Has been tested for syphilis at least once & & & & & & & 0.008 \\
\hline Yes & 371 & 35.9 & 619 & 41.6 & 990 & 39.3 & \\
\hline No & 566 & 54.9 & 795 & 53.3 & 1,361 & 54.0 & \\
\hline Don't remember/Don't know & 95 & 9.2 & 77 & 5.1 & 172 & 6.8 & \\
\hline Total & 1,032 & 100.0 & 1,491 & 100.0 & 2,523 & 100.0 & \\
\hline Syphilis serological scar & & & & & & & $<0.001$ \\
\hline Negative & 782 & 75.8 & 1,275 & 85.5 & 2,057 & 81.5 & \\
\hline Positive & 250 & 24.2 & 216 & 14.5 & 466 & 18.5 & \\
\hline Total & 1,032 & 100.0 & 1,491 & 100.0 & 2,523 & 100.0 & \\
\hline Active syphilis & & & & & & & 0.307 \\
\hline Negative & 1,001 & 97.0 & 1,460 & 97.9 & 2,461 & 97.6 & \\
\hline Positive & 31 & 3.0 & 31 & 2.1 & 62 & 2.4 & \\
\hline Total & 1,032 & 100.0 & 1,491 & 100.0 & 2,523 & 100.0 & \\
\hline Has been tested for HIV at least once & & & & & & & 0.660 \\
\hline Yes & 665 & 64.4 & 979 & 65.7 & 1,644 & 65.2 & \\
\hline No & 367 & 35.6 & 512 & 34.3 & 879 & 34.8 & \\
\hline Total & 1,032 & 100.0 & 1,491 & 100.0 & 2,523 & 100.0 & \\
\hline Most recent HIV test & & & & & & & 0.268 \\
\hline Within the last year & 189 & 28.4 & 312 & 31.9 & 501 & 30.5 & \\
\hline More than a year ago & 476 & 71.6 & 667 & 68.1 & 1,143 & 69.5 & \\
\hline Total & 665 & 100.0 & 979 & 100.0 & 1,644 & 100.0 & \\
\hline How many times has taken an HIV test in the la & t year & & & & & & 0.326 \\
\hline Once & 122 & 64.5 & 220 & 70.4 & 342 & 68.2 & \\
\hline Twice or more & 67 & 35.5 & 92 & 29.6 & 159 & 31.8 & \\
\hline Total & 189 & 100.0 & 312 & 100.0 & 501 & 100.0 & \\
\hline HIV test result & & & & & & & 0.006 \\
\hline Negative & 950 & 92.9 & 1,429 & 96.4 & 2,379 & 95.0 & \\
\hline Positive & 72 & 7.1 & 54 & 3.6 & 126 & 5.0 & \\
\hline Total & 1,022 & 100.0 & 1,483 & 100.0 & 2,505 & 100.0 & \\
\hline
\end{tabular}

${ }^{a}$ On the street and in brothels, predominantly.

${ }^{\mathrm{b}}$ Clubs, bars, hotels, motels, saunas and massage parlors. 
Table 4. Recruitment patterns of sex workers according to workplace. Brazil, 2009.

\begin{tabular}{|c|c|c|c|c|c|c|c|}
\hline \multirow{3}{*}{ Recruiter's workplace } & \multicolumn{6}{|c|}{ Participant's workplace } & \multirow{3}{*}{$\mathrm{p}$} \\
\hline & \multicolumn{2}{|c|}{ On the street ${ }^{a}$} & \multicolumn{2}{|c|}{ Indoor venues ${ }^{b}$} & \multicolumn{2}{|c|}{ Total } & \\
\hline & $\mathrm{n}$ & $\%$ & $\mathrm{n}$ & $\%$ & $\mathrm{n}$ & $\%$ & \\
\hline On the street and others & 477 & 52.0 & 555 & 34.6 & 1,032 & 40.9 & $<0.001$ \\
\hline Indoor venues & 440 & 48.0 & 1,051 & 65.4 & 1,491 & 59.1 & \\
\hline Total & 917 & 100.0 & 1,606 & 100.0 & 2,523 & 100.0 & \\
\hline
\end{tabular}

a On the street and in brothels, predominantly.

${ }^{\mathrm{b}}$ Clubs, bars, hotels, motels, saunas and massage parlors.

of gynecological examinations and regular syphilis testing; increase distribution of condoms, especially among the poorest FSW, so that they do not need to buy condoms; focus interventions on areas

\section{REFERENCES}

1. Aquilino WS. Privacy effects on self-reported drug use: interactions with survey mode and respondents characteristics. NIDA Res Monogr. 1997;167:383-415.

2. Baral S, Todd CS, Aumakhan B, Lloyd J, Delegchoimbol A, Sabin K. Literature review of HIV among female sex workers in the Central Asian Republics, Afghanistan, and Mongolia: contexts and convergence with drug use. Drug Alcohol Depend. 2013:132(Suppl 1):13-6

3. Barbosa-Jr A, Pascom ARP, Szwarcwald CL, Kendall C, McFarland W. Transfer of sampling methods for studies on most-at-risk populations (MARPs) in Brazil. Cad Saude Publica. 2011;27(Suppl 1):36-44. DOI:10.1590/S0102-311X2011001300005

4. Blankenship KM, Burroway R, Reed E. Factors associated with awareness and utilisation of a community mobilisation intervention for female sex workers in Andhra Pradesh, India. Sex Transm Infect. 2010;86(Suppl 1):69-75.

5. Boily MC, Lowdes C, Alary M. The impact of HIV epidemic phases on the effectiveness of core group interventions: insights from mathematical models. Sex Transm Infect. 2002;78(Suppl 1):78-90. DOI:10.1136/sti.78.suppl_1.i78

6. Borgatti SP. NetDraw Software for Network Visualization. Lexington: Analytic Technologies; 2002.

7. Buzdugan R, Copas A, Moses S, Blanchard J, Isac S, Ramesh BM, et al. Devising a female sex work typology using data from Karnataka, India. Int J Epidemiol. 2010;39(2):439-48. DOI:10.1093/ije/dyp351

8. Campbell AN, Tross S, Dworkin SL, Hu MC, Manuel J, Pavlicova M, et al. Relationship power and sexual risk among women in community-based substance abuse treatment. J Urban Health. 2009;86(6):951-64. DOI:10.1007/s11524-009-9405-0

9. Chersich MF, Luchters S, Ntaganira I, Gerbase A, Lo YR, Scorgie F, et al. Priority interventions to reduce HIV transmission in sex work settings in sub-Saharan Africa and delivery of these services. J Int AIDS Soc. 2013;16(1):17980. DOI:10.7448/IAS.16.1.17980 where FSW and clients with lower socioeconomic status are concentrated, where the FSW charge low prices; and empower the women to negotiate safe sexual practices.
10. Damacena GN, Szwarcwald CL, Barbosa Jr A. Implementation of respondent-driven sampling among female sex workers in Brazil, 2009. Cad Saude Publica. 2011;27(Suppl 1):S45-55. DOI:10.1590/S0102-311X2011001300006

11. Damacena GN, Szwarcwald CL, Souza-Jr PRB, Dourado I. Risk factors associated with HIV prevalence among female sex workers in 10 Brazilian cities. J Acquir Immune Defic Syndr. 2011;57(Suppl 3):144-52. DOI:10.1097/QAI.0b013e31821e9bf6

12. Ghys $P D$, Diallo $M O$, Ettiègne-Traoré $V$, Kalé $K$, Tawil O, Caraël $M$, et al. Increase in condom use and decline in HIV and sexually transmitted diseases among female sex workers in Abidjan, Côte d'Ivoire, 1991-1998. AIDS. 2002;16(2):251-8. DOI:10.1097/00002030-200201250-00015

13. Hao C, Liu H, Sherman SG, Jiang B, Li X, Xu Y, et al. Typology of older female sex workers and sexual risk for HIV infection in China: a qualitative study. Cult Health Sex. 2014;16(1):47-60.

14. Heckathorn DD. Respondent-driven sampling: a new approach to the study of hidden populations. SOC Probl. 1997;4492:174-99. DOI:10.2307/3096941

15. Heckathorn DD, Semaan S, Broadhead RS, Hughes JJ. Extensions of respondent-driven sampling: a new approach to the study of injection drug users aged 18-25. AIDS Behav. 2002;6(1):55-67. DOI:10.1023/A:1014528612685

16. Kathleen EW, Eric JTT, Jay GS, Megan BM. How does sex trafficking increase the risk of HIV infection? An observational study from Southern India. Am J Epidemiol. 2013;177(3):232-41. DOI:10.1093/aje/kws338

17. Kerr LR, Mota RS, Kendall C, Pinho AA, Mello MB, Guimarães MD, et al. HIV among MSM in a large middle-income country. AIDS. 2013;27(3):427-35. DOI:10.1097/QAD.0b013e32835ad504

18. Kissinger P, Rice J, Farley T, Trim S, Jewitt K, Margavio V, et al. Application of computer-assisted interviews to sexual behavior research. Am J Epidemiol.1999;149(10):950-4. DOI:10.1093/oxfordjournals.aje.a009739 
19. Lau JT, Tsui HY, Siah PC, Zhang KL. A study on female sex workers in southem China (Shenzhen): HIV-related knowledge, condom use and STD history. AIDS Care. 2002;149(2):219-33. DOI:10.1080/09540120220104721

20. Li J, Chen XS, Merli MG, Weir SS, Henderson GR. Systematic differences in risk behaviors and syphilis prevalence across types of female sex workers: a preliminary study in Liuzhou, China. Sex Transm Dis. 2012;39(3):195-200. DOI:10.1097/OLQ.0b013e31823d2e2a

21. Li Y, Detels R, Lin P, Fu X, Deng Z, Liu Y, et al. Difference in risk behaviors and STD prevalence between street-based and establishment-based FSWs in Guangdong Province, China. AIDS Behav. 2012;16(4):943-51. DOI:10.1007/s10461-011-0102-0

22. Malekinejad M, Johnston LG, Kendall C, Kerr LR, Rifkin $M R$, Rutherford GW. Using respondentdriven sampling methodology for HIV biological and behavioral surveillance in international settings: a systematic review. AIDS Behav. 2008;12(4Suppl):105-30. DOI:10.1007/s10461-008-9421-1

23. Medhi GK, Mahanta J, Kermode M, Paranjape RS, Adhikary R, Phukan SK, et al. Factors associated with history of drug use among female sex workers (FSW) in a high HIV prevalence state of India. BMC Public Health. 2012;12:273. DOI:10.1186/1471-2458-12-273

24. O'Reilly JM, Hubbard ML, Lessler JT, Biemer PP, Turner CF. Audio and video computer assisted selfinterviewing: preliminary tests of new technologies for data collection. J Off Stat. 1994;1092:197-214.
25. Pascom AR, Szwarcwald CL, Barbosa-Jr A. Sampling studies to estimate the HIV prevalence rate in female commercial sex workers. Braz J Infect Dis. 2010;14(4):385-97. DOI:10.1590/S1413-86702010000400014

26. Salganik MJ, Heckathorn DD. Sampling and estimation in hidden populations using Respondent-Driven Sampling. Sociol Methodol. 2004;3491:193-240. DOI:10.1111/j.0081-1750.2004.00152.x

27. Szwarcwald CL, Barbosa Jr A, Souza Jr PRB, Lemos KR, Frias PG, Luhm KR, et al. HIV testing during pregnancy: use of secondary data to estimate 2006 test coverage and prevalence in Brazil. Braz J Infect Dis. 2008;12(3):167-172. DOI:10.1590/S1413-86702008000300002

28. Szwarcwald CL, Souza-Jr PRB, Damacena GN, Barbosa-Jr A, Kendall C. Analysis of data collected by RDS among sex workers in 10 Brazilian cities, 2009: estimation of the prevalence of HIV, variance, and design effect. J Acquir Immune Defic Syndr. 2011;57(Suppl 3):129-35 DOI:10.1097/QAl.0b013e31821e9a36

29. Zhang C, Li X, Hong Y, Zhou Y, Liu W, Stanton B. Unprotected sex with their clients among low-paying female sex workers in southwest China. AIDS Care. 2013;25(4):503-6. DOI:10.1080/09540121.2012.726345

30. Zhou Y, Li X, Zhang C, Tan G, Stanton B, Zhang X, Cui $Y$. Rates of HIV, syphilis, and HCV infections among different demographic groups of female sex workers in Guangxi China: Evidence from 2010 national sentinel surveillance data. AIDS Care. 2013;25(11):1433-41. DOI:10.1080/09540121.2013.772282

This study was supported by the Ministry of Health/Secretariat of Health Surveillance/Department of STD, AIDS and Viral hepatitis, through the International Technical Cooperation Project AD/BRA/03/H34 between the Brazilian Government and the United Nations Office on Drugs and Crime - UNODC (TC/CFA/CSV - 239/2007).

Article based on the doctoral thesis of Damacena GN, entitled: "Análise de dados coletados por respondent-driven sampling (RDS): um estudo da prevalência de HIV e fatores associados entre mulheres trabalhadoras do sexo em 10 cidades brasileiras." presented to the Escola Nacional de Saúde Pública Sérgio Arouca of the Fundação Oswaldo Cruz, in 2012. The authors declare that there is no conflict of interest. 